\title{
THE EMPIRICAL ROLE OF SOCIAL CAPITAL ON URBAN TRANSFORMATION: A CASE STUDY OF ISTANBUL
}

\author{
Ö. ÖZÇEVIK ${ }^{1} \&$ P. TAN ${ }^{2}$ \\ ${ }^{1}$ Faculty of Architecture, Urban and Regional Planning Department, Istanbul Technical University, Istanbul. \\ ${ }^{2}$ Faculty of Architecture and Engineering, Architecture Department, Mardin Artuklu University, Turkey.
}

\begin{abstract}
The purpose of this study is to test the validity of the social capital knowledge that belongs to the local business community as an instrument for the formation of the initial strategies of urban transformation and to test the effect of independent variables in the formation of such social capital. This study takes as its point of departure the recently increasing interest in the role of social capital in planning and development, and the need for access to embedded knowledge in the sites of urban transformation. The lack of field data makes managing implementations of urban transformation difficult, and these implementations are not supported by appropriate policies. It is important to study this issue in İstanbul, which is going through the process of urban transformation and harbors a variety of resources for social capital due to its unique conditions. The hypothesis of this study, which aims to contribute to research being conducted in the field, is that the levels of security, belonging, awareness, and expectations inherent in social capital can change according to the profile of the small business community and according to the characteristics of the physical capital in sites of urban transformation. In this study, conducted in 2012, data from the neighborhood of Çeliktepe were collected using 'mixed methods social research.' Keywords: Social capital, local networks, small businesses, urban transformation, mixed methods social research.
\end{abstract}

\section{INTRODUCTION}

The role of social capital in planning, development and management has been attracting considerable scholarly attention of late, and the transformative effect that 'social capital knowledge' has on urban transformation has been emphasized. The literature on this topic reveals that the vast majority of research on social capital is based on results that derive from empirical surveys of social capital. It has not yet been discussed how social capital in İstanbul, where urban transformation discourse and its implementation have been accelerating since the 1999 Marmara earthquake, exhibits either transformative power or its own weaknesses.

The political discourse regarding urban transformation in İstanbul is based on the future of 'the buildings at risk of earthquakes.' Real-estate-focused urban transformation, underway since the 1999 Marmara earthquake, has been the main framework of the political discourse articulated in İstanbul. Demolishing buildings that are at risk of being affected by earthquakes and turning them into safer housing zones has been an important topic of political debate for both the private and the public sectors for over 10 years now. In the 2000s, political discourse on urban transformation focused on housing, whereas the populations that first migrated to the city and 'local businesses' located in the older neighborhoods were excluded from this political discourse. In a city like İstanbul, with its high trade volume, 'small local enterprises' have managed to survive in the midst of global and local pressures while being dwarfed by the rapidly rising office buildings in the smaller centers around the globe and by the hotels and residences that serve them. However, the national government's urban transformation policy that has developed in accordance with the need of housing, and 'the Law on Transformation of Areas under Disaster Risk,' which was put into effect in 2012, is not supported by economic and social policies other than those pertaining to the renovation of buildings. The initia- 
tives of the local authorities and civil society organizations regarding the integration of the local businesses, which are located on the ground floor of buildings, into the transformation process have been weak.

İnönü Avenue in the neighborhood of Çeliktepe, an example of a local business community that has managed to survive since the 1950s despite globalization, constitutes the site of our research. In the Haliç River basin, the culture-focused transformation and the transformation of old industrial sites are accelerating. Çeliktepe, on the other hand, awaits the housing-focused 'implementation of central urban transformation,' which will be carried out according to the new redevelopment law. Local businesses in Çeliktepe are not included in this redevelopment process. Considering the 'National Action Plans' and the funds directed toward small local enterprises during the process of accession to the EU, if small local enterprises are excluded from the implementation of urban transformation, we may predict that their contribution to the local and national economy and their effect on the diversification of the social structure will be diminished. When the local economic environment has the potential to be a catalyst for urban transformation, it becomes possible for local business to be included in the transformation process and to generate social and economic diversity.

The concept of social capital has been developed by means of empirical research. Empirical research furnishes strong evidence that societies with strong social capital have a much easier time dealing with urban transformation and being included in it. Although there are different approaches and opinions regarding the components of social capital, it is widely accepted that there is a need for the development of new studies that can determine the qualities, power, and effects of social capital. Age, gender, education, housing, and population and employment are seen as the independent variables that affect social capital, although there is just as much emphasis on the identification and selection of these variables as there is variety in the methods used to survey them. Knowing their effects, especially in areas undergoing urban transformation, will yield results that can guide policy planning.

Çeliktepe fieldwork was designed with the aim to contribute to the empirical literature on social capital and urban transformation and to the formation of the initial strategies for urban transformation by examining the social capital held by small enterprises. Social capital, as defined by Bourdieu, Putnam, Coleman, and Fukuyama, fundamentally sustains social cohesion and economic development. They see it as the basis of trust and belonging, but it may vary according to the profile and logistics of business in urban transformation areas. This research project aims to determine the power of the independent variables that influence social capital in urban transformation areas. Research data on the local business community were gathered using 'mixed methods research.' Our survey sample included all the businesses on the boulevard, selected using the 'one-to-one scanning technique,' and 234 local small businesses were identified in total. Of these businesses, 164 owners volunteered to participate in our survey. The qualitative data, an important component of mixed methods social research, derives from in-depth interviews with the leaders of business associations in the area. The results of our 2012 research in Çeliktepe support the idea that the dynamics that can be a catalyst for transformation are present in the local networks in İstanbul where urban transformation continues to be pursued by centralized political action. Çeliktepe's local business community has a very heterogeneous structure in terms of its management profile and physical capital. The structured environmental conditions in İstanbul's areas of urban transformation, ownership status, expectation of rent due to centralized authority structure, and the condition of uncertainty weaken the possibility of social capital becoming an effective power during the process of urban transformation. We presume that if civil society, government, and private sector initiatives work together to render the transformative power of social capital utilizable, it will become possible to develop strategies. Although the results from our fieldwork in an area that is expected to undergo urban transformation can contribute to empirical literature on the variables linked to social capital, they 
also present proven guidelines for the national and local governments' implementations of social capital-based urban transformation policies.

\section{LOCAL NETWORKS AND SOCIAL CAPITAL}

Small local businesses and production centers are located in social local networks in the urban fabric. Particularly in cities such as İstanbul, which is composed of social collectivities with diverse ethnic backgrounds and local identities, small local businesses operate within a social network that is dependent on intercity networks and kinship. On the other hand, the socioeconomic production and communication network that is produced by these kinds of small local enterprises reproduce the social network in the district or neighborhood (i.e. within their spatial parameters).

Granovetter's article on the question of embeddedness and his elaborations on 'the new sociology of economy' offers a novel introduction to the sociology of economy [1,2]. According to Granovetter, economic activities are situated as embedded in the social structure and relationships. Networks provide such embeddedness. For this reason, the main component of the concept of 'embeddedness' is 'the network of social relationships.' According to Granovetter, the economic interests of a person who is dependent on their physical environment are shaped by being embedded in social relationships. Cooperation in business matters, business clusters, and industrial groupings are the most distinctive elements in the network of social relationships.

In the 1990s, Castells developed the concept of 'network society,' and showed that urbanization is composed of heterogeneous networks and plural ethnic structures. According to Castells, 'the network' itself is a dynamic structure that is born out of the communication among urbanites and their spatial relationships. This network bears economic and technological effects. Intercultural, multicultural, and multiethnic spatial network structures will generate some kind of urbanization and metropolitanization, which influences the entire economic structure of the city. Castells describes network society as follows: 'Presence or absence in the network and the dynamics of each network vis-a-vis others are critical sources of domination and change in our society: a society that, therefore, we may properly call the network society, characterized by the pre-eminence of social morphology over social action' [3].

Cities have heterogeneous collective identities of varying sizes, and network societies can also vary because they are collective bodies that are formed as networks distributed among microfinance flows. Particularly in cities like İstanbul where various collectivities with distinct sociocultural identities (ethnic, migration histories, and kinship) live together, small-scale businesses rely on this sort of social morphology. These networked enterprises, which define this social morphology, are embedded in social relationships that generate mutual trust over time. The concept of social capital is used with these kinds of local networks.

The concept of social capital has one fundamental definition that has come to vary among social scientists and economists. It indicates mutual local relationships, a micro-economy that relies on a social network that stems from trust and the ownership of common property. Since the 1980s, Bourdieu, Coleman, Putnam, and Fukuyama have presented a variety of viewpoints on social capital. According to Bourdieu, social capital is based on institutionalized relationships, mutual recognition, and trust [4]. Coleman, on the other hand, analyzes the concept of social capital in relation to economic conditions of production and asserts that social capital has the function of making production easier by virtue of a collectivity's mutual trust [5]. Also, in the economic context, social capital exists in an informal manner in collective economy and production. According to Putnam, the ability to form associations and community are multiplied by means of accepted norms and trust, and increases in social capital at the local level can develop into region-wide development. When civil society organizations are few, participation in these institutions is low, and the sources of 
communication among citizens are inadequate, social capital is diminished, indirectly causing social and economic inequalities, and national and regional underdevelopment. The volume of social capital in a society is related to the degree of social unity and partnership in that society. The skills for establishing associations are developed through accepted norms and trust [6].

According to Fukuyama, in the contemporary world, all economic activities are accomplished by social organizations based on high-level social collaboration beyond individual efforts. 'Trust' is thus the fundamental component of social capital [7]. Social capital improves economic and social performance while a shared historical past and shared experiences shape informal norms and produce more social capital. For Uphoff, social capital can be understood as two interrelated categories: the structural and the cognitive. The structural category is related to roles, rules, procedures, and various organizations that contribute to collective action and broad cooperation [8]. The cognitive category concerns mental processes that result from being empowered by culture, ideology, norms, values, behaviors, and beliefs, and it results in an idea, as it enables cooperative behavior to form. Structural social capital is visible, but cognitive capital is not. However, structural capital and cognitive capital are connected to one another in practice. In this article, the importance of cognitive capital as a means to activate structural social capital is emphasized. The richness of the concept of social capital in the literature is increased by conceptual explanations of social capital, explorations of its dimensions, and the relationship between its components and its outcomes.

\subsection{The experimental measurement of social capital and urban policies}

The concept of social capital has a social and economic background. Social capital is often treated as an element that is important for satisfying individual and collective needs and in accomplishing socioeconomic objectives. Despite Bourdieu, Coleman, Putnam, and Fukuyama's efforts to delineate the concept of social capital and the various academic studies that have attempted to make the concept quantifiable, it is still difficult to measure social capital. According to Grootaert and Bastelaer, the topic of social relationships, networks, norms, and values in social development have been used in economics, sociology, anthropology, and political science, but only in the past 10 years has the idea of social capital been promoted as a transversal concept that incorporates these multidisciplinary viewpoints. Grootaert and Bastelaer claim that measuring social capital requires methodological richness just as much as it requires examples at the macro- and micro-levels. They emphasize that studies measuring the effect of structural social capital at the micro-level have shown progress, but that there is a need for studies that measure cognitive capital at the macro-level [9].

The difficulty of defining social capital is also reflected in its measurement. As the components in the measurement of social capital have been expressed in variables and relationships, the importance of experimental contributions has increased. Glaeser $e t$ al. who measured social capital using independent variables, claim that social capital strongly increases with property ownership and declines with the expectation of mobility. They argue that property ownership reduces rates of displacement and strengthens social capital. Variations in age, marriage, and family status are connected to movement [10].

Studies of the measurement of social capital show that the need for experimental studies is mostly pertinent in urban areas and local collectivities, which have different characteristics. In particular, the role that social capital plays in areas of urban transformation has gained more importance. Mayer relates the creation of 'social cohesion,' a key role played by social capital in the development of urban policies, to the close cooperation of local government, civil society organizations, and the private sector [11].

A few studies have been conducted on the role of the social capital of small local businesses in the process of urban transformation. For Raco and Tunney, like other types of urban collectives, 
small local businesses are not merely passive actors during the process of urban transformation [12]. On some occasions, they can act spontaneously to develop strategies for dealing with the transformation process. Whether this ability to act collectively can be developed depends on the power of social capital. During the urban interventions of local governments and national authorities, it is very important to sustain this capability of the local business community's local network.

According to Mehta, many governments today do not have extensive local knowledge on local communities [13]. The collaboration of local communities, the government, and the local business community when generating resources and solutions will be more sustainable and affordable as a whole in the long run. In İstanbul, too, local governments lack adequate information about the complex ethnic, religious, and microeconomic structures that are present in their districts. The local government's interventions that homogenize districts results in the partitioning and dividing of these social morphologies, which are dependent on different kinds of local networks and trust relationships.

There is a lack of collaboration among local governments, the collective body, and civil society organizations in Turkey regarding the issues of planning. Even though family ties and culture have preserved the structure of communities, particularly in Turkey's rural areas, Çekiç-İnal and Ökten attribute the main obstacle to the collective action for the development is the absence of a civil society tradition [14].

Experimental studies that measure social capital, particularly in urban areas, have also identified the key concepts that accompany social capital. These variables include the ability to make collective decisions, and the level of close cooperation between the local government, civil society organizations, and the community. By empirically measuring these variables that accompany social capital, key information can be gathered, which will allow for the inclusion of local enterprises in the process of urban transformation.

Informal small enterprises, which operate through mutual trust and unofficial structures, form the economic backbone of numerous local urban communities in İstanbul. The outcomes of urban transformation include migration, displacement, the disintegration of local identities, and the destruction of social morphology due to the displacement of communities and property transfers. Thus, small business networks that are closely knit by social morphology face the danger of being dissolved by the process of urban transformation.

When considered from the angle of urban transformation practices in İstanbul, it can be seen that effects of large urban transformation projects and planning processes on the small enterprises that fall under local networks in the urban system are not taken into account, and that they do not exist as a 'local community' included in the processes of urban transformation. For the past few years, local and national governments consider urban spaces only as physical spaces when implementing urban transformation, and they overlook the fact that these are at the same time social and economic spaces, which are produced by shared common experiences, ties, and trust. To support the hypothesis of this study, İnönü Avenue which is the main trade axis of Çeliktepe Neighborhood, a prospective urban transformation site, was designated as the main research site.

\section{RESEARCH SITE AND DESIGN OF RESEARCH}

3.1 İnönü Avenue and the neighborhood of Çeliktepe as a research site

Çeliktepe is located in one of the most strategic locations in the European side of İstanbul, and belongs to the Kağıthane district (Fig. 1). 


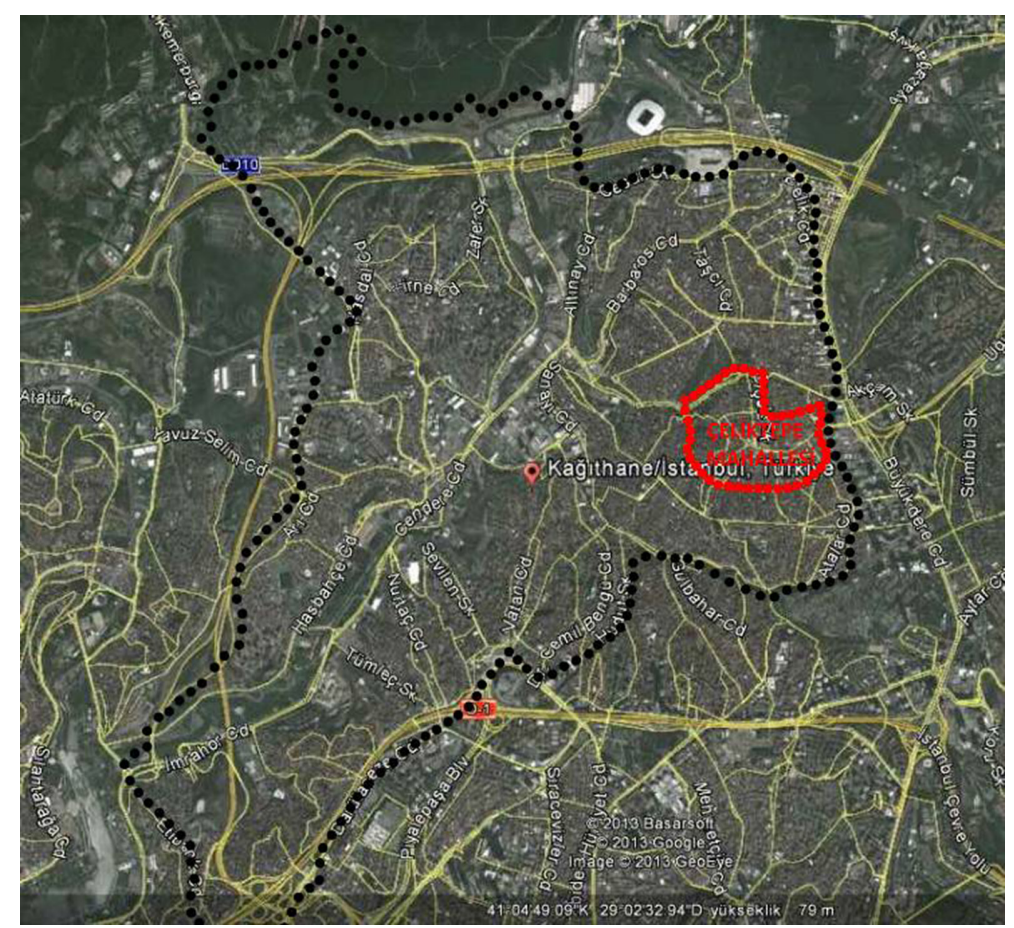

Figure 1: Çeliktepe's location in the Kağıthane district.

The population of Kağıthane was 419,865 in 2011. Over the years, Kağıthane's share in the overall population of İstanbul has increased. Its migration history explains how this district has transformed from a small village to a city district in such a short period. Çeliktepe is one of the destinations that receive the most immigrants in İstanbul. Altınok [15] evaluates the meaning of Çeliktepe's particularly strategic position in İstanbul in the context of this historical process and identifies the stages of this neighborhood's process of urbanization. In the 1950s, Çeliktepe was administratively considered a 'village.' The village of Çeliktepe gained advantages with the implementation of industrial complexes and the first social housing projects. Due to the changes in the area, empty lots were put on sale and land speculation began in Çeliktepe.

With the momentum of rental property construction projects, which began in Çeliktepe in the 1950s, unauthorized and rapidly developing housing infrastructure, or squatter settlements (gecekondu) proliferated. Until the 1960s, areas where there was electricity, water, sewage, or roads in the village of Çeliktepe became the first focal points for settlement. In the 1970s, with the enactment of the Gecekondu legislation, Turkish Act 775, the space was completely legitimized. Between 1975 and 1985, amnesty laws, Turkish Acts 2805, 2981, and 3290, were passed. These laws began to affect the spatial design. The introduction of improvement and development plans solidified the effects of the amnesty laws, and the transformation began with 'the process of qualitative transformation.' According to Altınok, Çeliktepe saw three distinct stages of squatter development in the transformation processes of illegal housing from 1985 until today. The first stage has still not undergone complete transformation and can be identified as the establishment of pure squatter houses. The second stage is the built-up fabric that is constituted by small lots in central Çeliktepe, which have been transformed from 'parcels under joint ownership'. The third stage, on the other hand, 
concerns the areas that face Büyükdere Boulevard that have completely been transformed and urbanized. The research area includes all the spatial, social, and economic traces of these three stages.

A new İstanbul is being shaped by local political decisions and national government policies wedded to neoliberalism. Although the national government launches new projects, it enacted legislation concerning the transformation of buildings at risk of earthquakes. This idea of a new İstanbul is also applicable to Çeliktepe, which is a focal point for new investments and expectations of urban transformation formed in the framework of neoliberal policies along with the traces of the historical process in the urban space. In this new İstanbul, the Levent-Maslak line, a center of finance and trade, has maintained its stature and is even expanding due to new investments. However, the financial borders of the İstanbul have been delimited by the old neighborhoods (Fig. 2), which are at risk of earthquakes and are expected to be transformed by legislative acts. Thus, the financial center is intermingled with the neighborhood fabric; this process began in the 1950s and has undergone several important stages. İstanbul Sapphire was built on Büyükdere Boulevard. It is one of the most important centers in İstanbul and the tallest shopping center and residence building in Turkey. 'Sapphire's backyard' is the nickname that the residents of Çeliktepe have adopted for their neighborhood (Fig. 2). This nickname can be seen as an important reference point for a neighborhood that is grappling with neoliberal investments.

Çeliktepe is adjacent to the financial center and is expected to become the site of 'first-class' housing, finance, and shopping centers. However, this is a very problematic area in terms of settlement and development. Built in illegal housing areas that are not protected from earthquake risk, office and commercial buildings and older houses coexist in the neighborhood. Throughout this entire process, singular building transformations have been progressing in Çeliktepe. In many cases, efforts to keep up with the 'neoliberal footprints' and generate value have consisted in merely 'renovating the buildings' facades' rather than demolishing and reconstructing the buildings.

Meanwhile, Çeliktepe's small local enterprises have been excluded from both the Transformation Law (Turkish Act 6306) and political discourse [16]. The law and policies focus on the structural risks of the buildings, but they do not consider how risks such as the eradication of the local businesses

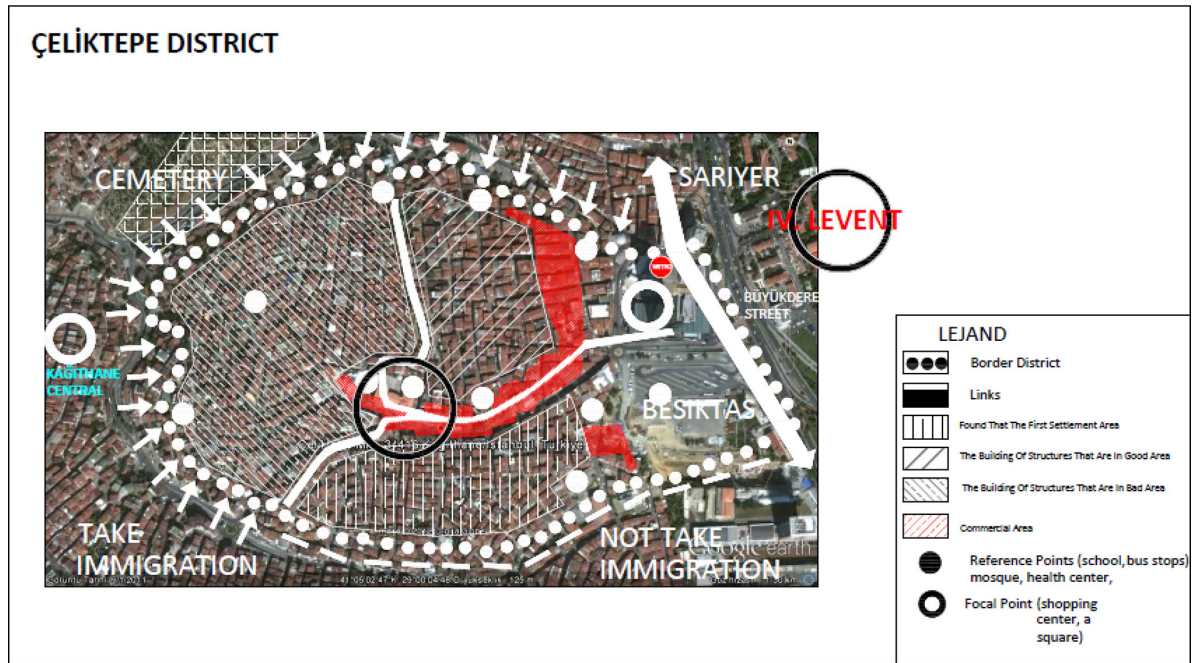

Figure 2: The local business street in Çeliktepe. 
located on the ground floor of these buildings and the loss of the employment they provide will modify the urban fabric. Çeliktepe's local business community has developed parallel to the Büyükdere financial capital since the 1960s.

Local business communities affected by looming urban transformation are left out of the political and legal discourse, but the knowledge that belongs to their local networks has an important role to play in their inclusion in the process. Experimental research indicates that during the process, it should be possible to support and include the local business communities that have the capacity to transform and show resilience in the process. The social capital of the local business community counts as one of the most important factors allowing for the inclusion of retail businesses, which have no cultural content, in the transformation process. However, which components of the local business community's social capital are active needs to be determined.

\subsection{The purpose, method, and design of the research project}

To discuss 'initial strategies for urban transformation' for local business communities that are expected to undergo urban transformation, this study examines the qualitative and quantitative components of social capital in the local area. Designed research postulates that the levels of trust, belonging, and knowledge that are posited for social capital can vary according the profile and physical properties of the local businesses in areas of urban transformation. To garner the data from the local area, the research design looked for the answers to the following set of questions: What are the profile and physical properties of Çeliktepe's local commercial center? What are the local business community's levels of trust, knowledge, belonging, and satisfaction? Is their social capital sufficient for them to be resilient and to be included in the process of urban transformation? Are they really being included in decision making during the transformation process? Do small enterprises have anything to say about urban transformation? Would they like to be a part of the deliberative process? Do they have any ideas that could shape the transformation process? If not, what plans do these small enterprises have for the future? This study considers the local workforce and the general profile of the workplace, the customer and supply network, initiatives that are geared toward improving business, and the priorities of the small local enterprises in the area in determining their strategies for being a part of the urban transformation, their perception of and expectation from the past, present, and future while anticipating urban transformation.

The fieldwork was made possible by support provided by İstanbul Technical University's Scientific Research Project Unit in 2012. During the data collection stage, primary sources were collected by using 'mixed methods social research.' Here is the basic definition of mixed methods social research; according to several researchers such as Claire Hewson: 'The combined use of both quantitative and qualitative methodologies within the same study in order to address a single research question' [17]. Mixed methods research means collecting, analyzing, and interpreting quantitative and qualitative data for the same fundamental phenomenon in a single study or series of studies [18]. The mixed methods research paradigm has been used since the 1960s in the fields of education, health, and psychology, and has been used in studies on urban areas and social capital, which require more participation. In the case of studies on local business communities' social capital, qualitative analysis has been emphasized [19]. It has been claimed that collecting and analyzing the embedded qualitative answers makes it possible to explain or supplement complex or contradictory survey results [20].

In Çeliktepe, an 'embedded design' typology was used. In an embedding strategy, a supplemental qualitative strand is embedded in a larger quantitative design [21]. It was chosen the mixed methods research paradigm so as to discover the 'codes' that are not visible within social capital by combining the quantitative data with the additional qualitative data. This research used a 'pragmatic 
knowledge claims, collection of both quantitative and qualitative data sequentially' in order to be open for the emerging data from the site as it is an urban site that is under a rapid transformation and multiple actors' affects [22].

In this research we used secondary data from the relevant news articles on urban transformation discourse. This data cluster includes the local government's decisions concerning urban transformation in the socioeconomic and spatial contexts and background information. The primary data used empirical data from observation, in-depth interviews, and surveys. These interviews made it possible to share the ideas of representatives of small enterprises regarding urban transformation. Before the surveys and interviews, a pilot study was conducted and possible reactions were observed. After the pilot study, a field study was conducted on İnönü Avenue, which is densely packed with small enterprises. The interviews planned to ensure that the customer flow of these small enterprises would not be interrupted. In the survey sample, all of the businesses on the boulevard were selected by 'the one-to-one scanning technique,' and 234 local small businesses were identified. Of this group, 164 business owners volunteered to participate in the survey. The survey is based on quantitative parameters. These are business profile, physical characteristics, satisfaction, future plans, perception, knowledge, trust, shared principles, and strategies. The qualitative data, which is an important source of information for mixed methods social research, was acquired by conducting in-depth interviews with four leaders of local business associations. The in-depth interviews used the parameters of membership, location, physical structure, ownership, social relationships, physical characteristics, and trust to maintain the flow of the conversations.

The quantitative data from the survey results generated frequency distributions in accordance with the results of the reliability test. Qualitative analysis, on the other hand, is achieved by transcribing the in-depth interviews and thoroughly analyzing the content of these interviews. At the end of the analysis, the qualitative data was interpreted by embedding them in the quantitative data. To determine the effect of the codes that resulted from quantitative data on the dependent variables, analysis of variance (ANOVA) was conducted. Whenever there was more than one dependent variable, instead of conducting many $t$-tests and an ANOVA, multivariate analysis of variance (MANOVA) was conducted.

\section{FINDINGS FROM THE FIELDWORK}

\subsection{The local business profile and physical characteristics}

The local business owners are 'shopkeepers' who are part of a dynamic local business community. They are at their prime working age and educated. They have social security and contribute to their local business community by investing in their neighborhood's retail sector. The businesses on İnönü Avenue are small enterprises that employ locals. They tend to have one or two full-time employees, most of whom reside in the neighborhood where they work, commute on foot, and have received in-service training. These businesses operate in spaces of less than $50 \mathrm{~m}^{2}$, and they are located on the ground floor of their buildings. There is a high rate of renters among those who operate on İnönü Avenue. Most of these businesses have been in business for 10 years (Table 1).

During the in-depth interviews, the local associations for shopkeepers on Çeliktepe's İnönü Avenue described the condition of the buildings where the local businesses operate as unfavorable:

...The local shopkeepers of course have been in the same spot for 30 years, 35 years, or 40 years. For example, I have been running the same business in the same location in Çeliktepe for 22 years. The building where I am located was built in 1975. So the health of this building is in jeopardy. Also, in the years since these neighborhoods were established, there have been crooked buildings, and the streets were narrow. Shops, this and that... Someone comes and parks. Let's 
Table 1: Business profile and physical characteristics.

\begin{tabular}{lllc}
\hline Components & Subdomain parameters & Max. rate & $\begin{array}{c}\text { Frequency } \\
(\%)\end{array}$ \\
\hline \multirow{5}{*}{ Business owner profile } & Age & 25-44 years & 58.5 \\
& Gender & Male & 84.8 \\
& Birth place & Primary + secondary & 87.8 \\
& Occupation & Outside of İstanbul & 62.2 \\
& Business branch & Shopkeeper & 76.8 \\
& Social security & Retailer & 72.6 \\
\multirow{5}{*}{ Human resources } & Yes & 98.2 \\
& Neighborhood of residence & Kağithane district & 73.2 \\
& Number of employees & 1 or 2 & 70.1 \\
& Work status of employees & Full time & 99.4 \\
& In-service training of employees & 1 or 2 Employees & 51.8 \\
& Residence of employees & Çeliktepe neighborhood & 56.1 \\
& Type of commuting & On foot & 50.0 \\
Physical characteristics & Building type/location & Building's ground floor & 93.3 \\
& Property ownership & Renter & 67.7 \\
& Shop size (m ${ }^{2}$ ) & Less than 50 & 60.4 \\
& Business's sge & 0-10 Years & 70.1 \\
\hline
\end{tabular}

say that his work is fixing car interiors. He is one of us in the neighborhood, our own shopkeeper, our member. His shop is small; he cannot go in with the car. What will he do? He will do his business in front of his shop, and interrupt the traffic flow. Since the roads are narrow, we have these kinds of troubles, plus since the buildings are old, there is also that problem...

The local business associations stress that since most local businesses are renters facing an anticipated urban transformation, these businesses are likely to lose the future struggle against displacement:

...The shopkeepers are worried and concerned. The property owners are not. The owners say that we will live in nicer and safer buildings with playgrounds, pools, elevators. The owner says, "I have five apartments, if they give me five apartments, my job here is done." So he is happy about this.... This is only applicable to property owners of course. The shopkeepers are naturally worried. He will not find the same environment and the same shop. Maybe in these new buildings, there won't be shops on the ground floor, or each building will have only one shop...

...So we say that when urban transformation is implemented in the context of this section, the shopkeepers in this section should be kept in mind and there must be certain guarantees given to the shopkeeper's business. But of course, the burden falls on the shopkeepers'shoulders. But the owner thinks just the way I said before. He says that from now on, I will live in places with pools, parking space, green parks to walk around-in a place with an elevator. I will go inside the building with my car and I will get out of my building without even stepping outside of it. But this is only for the property owners. But at the first stage, he does not think about the shopkeepers below him. He only looks at himself. But the shopkeepers are anxious, of course. We say that as the urban transformation is being implemented, do we take this section as our base? Let's say there are four or five shopkeepers in this city block, will they be taken into account during the transformation, will they still be located here after the transformation is implemented? 
...If the value of the buildings rises due to urban transformation, I believe that the shopkeepers will leave. They will not be able to pay the rent, and they cannot give 10 liras for a place that is worth 3 liras. The amount is not that important. I mean for our shopkeepers the rent is a very important thing. For that reason, I do not think that the shopkeepers will be able to return to these areas after urban transformation...

In interviews conducted with the directors of local business associations 'renting, 'owning property,' and 'the inadequacy of building conditions and the earthquake risk' were identified as fundamental codes. Renters have little power to transform the local business community. Property owners show no reaction to the failure to include the local business community in the process of urban transformation, and they support the transformation of the business community into residential buildings.

\subsection{Location, satisfaction, and future plans}

The factor that has the highest impact value in choosing this area for business is the satisfaction of being located on İnönü Avenue (Average impact 4.1/5). Businesses acquire retail products from towns nearby. The customers are located in Çeliktepe and surrounding areas. The business area satisfies demand. The supply and service area for the local businesses is within reasonable distance. For that reason, the local community in the Çeliktepe neighborhood relies on 'local capital and a local work force'. Local businesses do not wish to move elsewhere. Given the expectation for urban transformation, the level of investment in social and physical capital is low (Table 2).

During in-depth interviews, the local shopkeeper associations related the development of Çeliktepe İnönü Avenue to its historically central location and the current investments in shopping malls in the surrounding area:

...Because of the construction of large shopping malls in Çeliktepe, the shopkeepers are becoming more clustered from Emniyetevler to the Çeliktepe gateway. This means that there is also a very old housing site and a very old, large avenue, and the street front is very open. You go from

Table 2: Location, satisfaction, and future plans.

\begin{tabular}{|c|c|c|c|c|}
\hline Components & Subdomain parameters & Max. rate & $\begin{array}{l}\text { Frequency } \\
\quad(\%)\end{array}$ & $\begin{array}{l}\text { Average } \\
\text { impact }\end{array}$ \\
\hline & Location choice & $\begin{array}{l}\text { Proximity to the } \\
\text { customers }\end{array}$ & & $3.5(4)$ \\
\hline & Supply of commodity & City center & 75.0 & \\
\hline & Customer profile & $\begin{array}{l}\text { Local Environment/ } \\
\text { neighborhood }\end{array}$ & 82.5 & \\
\hline \multirow{5}{*}{$\begin{array}{l}\text { Location, satisfaction, } \\
\text { and future plans }\end{array}$} & Adequacy of space & Satisfies the need & 47.0 & \\
\hline & $\begin{array}{l}\text { Plans for expanding the } \\
\text { space }\end{array}$ & None & 59.1 & \\
\hline & Use of credit & None & 97.6 & \\
\hline & Relocation plans & None & 46.3 & \\
\hline & $\begin{array}{l}\text { Satisfaction level of the local } \\
\text { business community }\end{array}$ & Satisfied & & $4.1(5)$ \\
\hline
\end{tabular}


Levent to Sapphire through this area straight to Kâğlthane. This means that its front is wide open and there are businesses left and right...

The prevalent opinion is that the rent for spaces on İnönü Avenue is rising steadily:

...The highest retail levels and rent gains in Çeliktepe, as a business, the main street, what we call Inönü Avenue, which starts at Sapphire and keeps going, the real estate prices and the rent prices for both shops and business offices are very high..

The leaders of local shopkeeper associations shared the opinion that the Inönü Avenue location is advantageous, which raises rent prices even more.

\subsection{Perception, knowledge, and trust}

The local business owners in Çeliktepe define urban transformation as reinforcing buildings to make them earthquake resistant. Kağıthane, the district where these businesses are located, is to a large extent aware of and knowledgeable about urban transformation practices, but business owners do not know how their own local business community will be transformed, and they are concerned. The shopkeepers' level of trust in the local business community is 2.9 on a 4-point scale. 2.9/4. The shopkeepers' level of trust in the local government is 3.7/4 (Table 3).

In the in-depth interviews with the local shopkeeper associations with regard to the level of interaction and trust between the owners of the local businesses on İnönü Avenue and the local government, it is emphasized that there is a high level of trust between the local business owners and local government, and among the business owners:

...Kâğthane district is very lucky in this regard. We would again like to thank the mayor of Kâğlthane through you. He is really very engaged with the business owners and the public, but particularly with the former. He is always visiting the business owners. He goes to them, asks about their grievances, and listens to their problems on the spot.

Table 3: Perception, knowledge, and trust.

\begin{tabular}{|c|c|c|c|c|}
\hline Component & Subdomain parameter & Max. rate & $\begin{array}{l}\text { Frequency } \\
\qquad(\%)\end{array}$ & $\begin{array}{c}\text { Average } \\
\text { level }\end{array}$ \\
\hline & $\begin{array}{l}\text { Perception of urban } \\
\text { transformation }\end{array}$ & $\begin{array}{l}\text { Buildings resistant } \\
\text { to earthquakes }\end{array}$ & 53.7 & \\
\hline & $\begin{array}{l}\text { Knowledge about the laws } \\
\text { on urban transformation }\end{array}$ & None & 60.4 & \\
\hline \multirow[t]{5}{*}{$\begin{array}{l}\text { Perception, knowledge, } \\
\text { and trust }\end{array}$} & $\begin{array}{l}\text { Knowledge about the rumors } \\
\text { in the neighborhood }\end{array}$ & Aware about & 93.9 & \\
\hline & Source of information & Media & 65.6 & \\
\hline & $\begin{array}{l}\text { The information that the local } \\
\text { business will be included in } \\
\text { urban transformation }\end{array}$ & Nonexistent & 82.3 & \\
\hline & Trust & Among shopkeepers & & $2.9 / 4$ \\
\hline & & $\begin{array}{l}\text { In the local } \\
\text { government }\end{array}$ & & $3.7 / 4$ \\
\hline
\end{tabular}


He helps them to a great extent. Our people are really very lucky in that regard. The level of trust is quite good... There are educational and cultural events for the local business owners... Regarding the issue of hygiene, there are information sessions for the manufacturers, for those who produce sweets, bakers, grocers, shops, with the assistance of the district's agricultural department, which brings in teachers and food engineers.

...We are sending messages; of course, the business owners who are more related to that field participate more... In that sense, the municipality supports us more like this... for example, we are receiving vehicles-buses for transporting the people from their neighborhoods to here. Whenever we ask for these services, we always get them.

...There are no problems for us in terms of the way business owners interact with one another. Even for people who are in the same business, we see no major problem...

The local shopkeeper associations on İnönü Avenue see the anticipation of urban transformation as having a negative effect on the local business owners:

... Of course, these business owners are worried when this system breaks down. We know this, we are talking to them, and we share their concerns, but the main thing that we ask from the authorities is naturally the following: while implementing this transformation, protect and take care of the small business owners. They should, of course, provide good terms and conditions to these people, which would be those conditions under which they can go on with their jobs. We are constantly talking about these things with the business owners. Most of them are stricken; they cannot do their jobs. The municipality intervenes and implements penal sanctions for blocking the road. The owners, of course, want to work in better and more orderly conditions. From our perspective, it would be better if the government could implement this transformation without overlooking these people and by providing better conditions for them. This is our view. At the end of the day, everyone would like to work in a nice place that's on the ground floor of good buildings... In terms of soil structure, our area is the most stable one, but under what conditions were the buildings on this land built thirty to forty years ago? We see that sea sand was used, and the columns are thin. This means that whenever there is an earthquake, both life and property are lost. Okay, they should be transformed and renovated, but while implementing this transformation and renovation, our business owners, or small business owners, who are the backbone of the Turkish economy, need to be taken care of and protected...

The local shopkeeper associations stated that the local businesses on İnönü Avenue, particularly the local business owners who are renters facing the prospect of urban transformation, perceive the urban transformation positively, but that they have certain reservations due to their renter status.

...The business owners who are seen as lacking a solution are those who rent. For this reason, people have the idea that "once these areas are transformed, we will lose our businesses, and we can never come back here." But the property owners do not share this thought. They are more concerned about how to preserve their property and how to increase its value. The owner does not consider the absence of a renter or the business owner declaring bankruptcy. Naturally, business owners are cautious. They are saying, "I am a small business owner here. I am fixing laundry machines, dishwashers, and small house appliances. Will I still be able to make it here after the transformation? Will I be able to provide this service to people?"...

...They are worried that when urban transformation takes place, the area will be apartment complexes, and they will lose their shops and will not be able to find these jobs again. Right now, they are continuing their activities on the ground floors of three-to-five-story buildings. They naturally think that when these complexes are built, there will no longer be spaces for these shops; this entire area will be housing. Even if there is space for the shops, they are not going to be able to find space for themselves. The property owners and contractors will never 
give these places to them. We are talking about these things; we receive such complaints. They are worried that if urban transformation occurs, they won't be able to establish their businesses. ...Right now, people have a certain order; they put bread on the table, but after urban transformation, they cannot calculate the rest since they think that they won't be here.

\section{EXPECTATIONS OF URBAN TRANSFORMATION STRATEGIES}

The average desire in the local business community for the implementation of urban transformation is 3.1 out of 4 . In the levels of significance that are expressed by the local enterprises regarding the main principles of urban transformation projects, the project being able to finance itself, renters remaining in

Table 4: Expectations of urban transformation strategies.

\begin{tabular}{|c|c|c|c|}
\hline Component & Subdomain parameter & Max. importance rate & $\begin{array}{l}\text { Average } \\
\text { importance }\end{array}$ \\
\hline & & $\begin{array}{l}\text { Inclusion of the local business } \\
\text { community in the urban } \\
\text { transformation process }\end{array}$ & 3.6./4 \\
\hline & & Local transformation program & 3.3./4 \\
\hline & $\begin{array}{l}\text { The level of anticipation } \\
\text { for the initial strategies } \\
\text { for urban transformation }\end{array}$ & Cultural and esthetic activities & 3.4./4 \\
\hline \multirow[t]{11}{*}{$\begin{array}{l}\text { Level of } \\
\text { anticipation }\end{array}$} & & $\begin{array}{l}\text { Economic development transformation } \\
\text { program for neighborhoods }\end{array}$ & 3.5./4 \\
\hline & & Formation of a participatory platform & 3.4./4 \\
\hline & & $\begin{array}{l}\text { Level of trust in local government and } \\
\text { among business owners }\end{array}$ & 3.6./4 \\
\hline & & The self-financing of the project & 3.5./4 \\
\hline & & $\begin{array}{l}\text { The property owners remaining in the } \\
\text { area after the project }\end{array}$ & 3.5./4 \\
\hline & & $\begin{array}{l}\text { The renters remaining in the area after } \\
\text { the project }\end{array}$ & 3.5./4 \\
\hline & $\begin{array}{l}\text { The implementation } \\
\text { principles for the } \\
\text { transformation project }\end{array}$ & $\begin{array}{l}\text { The survival of the social fabric after } \\
\text { the project }\end{array}$ & 3.4./4 \\
\hline & & $\begin{array}{l}\text { Generating consensus among } \\
\text { administration, property owners, } \\
\text { and renters }\end{array}$ & 3.4./4 \\
\hline & & $\begin{array}{l}\text { Providing a participatory platform for } \\
\text { business owners/local government/ } \\
\text { implementing institution in the area }\end{array}$ & 3.4./4 \\
\hline & & Projects to increase trade in the area & 3.5./4 \\
\hline & & $\begin{array}{l}\text { Providing space for cultural and esthetic } \\
\text { activities and locations to enliven } \\
\text { trade in the area }\end{array}$ & $3.6 . / 4$ \\
\hline
\end{tabular}


the area after the project, and keeping trade alive through cultural and esthetic events stand out with an average of 3.5 out of 4 . When local businesses are asked to express the level of significance they attribute to the initial strategies of urban transformation projects, they attribute high significance to including the business units in the area in the urbanization process (average 3.6/4), ensuring a situation where there is communication among local businesses during urban transformation and where there is an environment of trust that is geared towards taking collective decisions (average 3.6/4) and establishing economic development programs for the neighborhoods (average 3.5/4) (Table 4).

The local shopkeeper associations stated that the local businesses want to 'be protected and included during the urban transformation.'

.... When we go to visit the business owners and when they come to us, inevitably, we talk about urban transformation and about the section. For example, in those places that we visit, they say,

"Dear president, in terms of this section, the contractors came to talk about this section and presented certain proposals. This and that happened... What is going to be our situation here?" Of course, they are worried. We talk about this. This is the primary item on our agenda. We talk about this all the time. And in relation to the authorities, during urban transformation, we maintain that it should done while protecting the small business owners. This is what we want. This is our utmost priority in this urban transformation. We are sharing this idea with the mayor during the municipality meetings. As this is being done, the business owners in this section, let's say that this section is being bought, what is here, there is a bakery, a hardware store, what is here? There is a tailor store. What is here? A shop. Again, these should be taken into consideration while implementing this transformation. In the upcoming days, again, these people will be served. These services will again be given to the people who live here. This means we are expressing our opinion and speaking for the purpose of protecting them...

The local shopkeeper associations said that the local business owners on İnönü Avenue have emphasized their expectation that 'the local business owners will be protected during urban transformation' and about the development of strategies pertaining to renters and their ability to stay.

...Being a business owner cannot be a precondition there because they are renters. Only for the property owners can this happen. As the property owner does the negotiation, he is making the agreement while also taking his own condition into account. But what will the renter do? After making a deal regarding the place, he says, "Okay, brother, get out of here," or when the lease runs out, "Get out, I sold my place." At this point, it is like... I mean, the renter is a burden here. As this urban transformation is being implemented, the local government or the state should take care of them. As I explained earlier, urban transformation needs to be implemented with consideration for the people who provide service in the area...'

Expectations regarding both the property owners and the renters being able to stay in the area featured prominently in our interviews with the local shopkeeper associations:

...It is, of course, important for the property owners to remain in the area. Let me give you another example from my own experience. Urban transformation also concerns my own neighborhood. It concerns the area where my house is situated, which is the section. Of course, whatever the circumstances might be, I hope to remain in my neighborhood and in my own place because I have grown accustomed to my neighborhood. It would be very difficult to live or reside and to work in a different location. For example, for the past twenty-two years, I have been serving the same people here. Everyone got to know me and I got to know everyone. There is mutual trust among us. I have figured out how to do things, how to shop. Everything is in order. After this, moving to a different place would be very hard. It would take time. I mean, it would take years... 
...A business owner has established a habitat. It is logical for him to stay in the area. At the end of the day, he has established a habitat. A business owner for fifteen years. He will leave the neighborhood after the urban transformation. This means that he will find a new habitat, new people, and so on... Small business owners need to be protected...

The qualitative and quantitative findings show that both the directors of the business associations and the local business community have quite similar expectations regarding the main tactics and the issues of inclusiveness in the process of urban transformation and initial strategies.5.1

\subsection{The level of influence of independent variables}

Research findings show that the main components of social capital, belonging, trust, awareness, and expectations have strong potential to help develop policies for urban transformation, but quantitative analysis shows that 'physical characteristics,' particularly ownership status, affects social capital and weakens ties. Since being a renter was emphasized as a code in the findings that were acquired by qualitative analysis, the MANOVA was used to determine whether a group of independent variables has any effect on belonging, trust, and expectations. In situations where there is more than one independent variable, instead of applying many $t$-tests and variance analysis, MANOVA was used. The independent variables used in this research are gender, age, the life span of the business, ownership status, and the physical condition of the place of business. Dependent variables, on the other hand, include the business community's satisfaction levels, trust among the shopkeepers, the shopkeepers' trust in the local government, and the expectations regarding the implementation of urban transformation.

\subsection{Gender}

According to the results of analysis, gender has an effect as statistically significant as the level of significance accorded to having the local government and/or implementing institution provide a participatory platform for the local business owners $(\mathrm{p}<0.05)$. According to the observed levels of causality in the variables, the gender variable is most effective at the level of significance accorded to the inclusion of the property owners and renters during the transformation project's decisionmaking process $($ Power $=0.631$ ). The causal effect of gender on belonging and trust is not strong.

\subsection{Education level}

According to the results of our analysis, individuals' level of education does not have a statistically meaningful effect on any of the dependent variables ( $p>0.05$ ). According to the observed causal levels of the variables, the education variable has the most significant effect on the variables of the level of importance accorded to the participation of the property owners and renters during the transformation project's decision-making process (Power $=0.561$ ) and the level of satisfaction in the local business community (Power $=0.440$ ). The causal effect of education on trust is not strong.

\subsection{Age}

According to the results of our analysis, the individuals' age level has an effect as statistically significant as the level of significance accorded to the implementation of the transformation project's inclusion of efforts to enliven trade in the area and the satisfaction of owning a business in this part of the city $(\mathrm{p}<0.05)$. According to the observed causal levels of the variables, the age variable has 
the highest impact on the variable the level of feeling of satisfaction in owning a business in this part of the city (Power $=0.825)$, and the principle of the method being chosen for working on enlivening the trade in the area (Power $=0.679)$. The causal effect of age on trust is not strong.

\subsection{Place of residency}

According to the results of our analysis, the district where individuals reside has an effect as statistically significant as the level of significance accorded to the self-financing of the projects and having the local government and/or implementing institution provide a participatory platform for the local business owners $(\mathrm{p}<0.05)$. According to the observed power levels of the variables, the residency variable is the most effective on the level of significance accorded to the self-financing of the urban transformation project (Power $=0.982$ ). The other variables on which the residency variable is effective are satisfaction $($ Power $=0.479)$ and trust in the local government $($ Power $=0.384)$.

\subsection{Ownership status}

According to the results of our analysis, ownership status has an effect as statistically significant as the level of significance accorded to having the local government and/or implementing institution provide a participatory platform for the local business owners $(\mathrm{p}<0.05)$. According to the observed power levels of the variables, ownership status is the most effective on the level of significance of having the transformation project's local government and/or implementing institution provide a participatory platform for the local business owners (Power $=0.784)$. The causal effect of ownership status on belonging and trust variables was not high $($ Power $=0.144$ and Power $=0.285)$.

\subsection{Building location}

According to the results of our analysis, ownership status has an effect as statistically significant as the level of significance accorded to the self-financing of the urban transformation project and having the local government and/or implementing institution provide a participatory platform for the local business owners $(\mathrm{p}<0.05)$. The variable on which the building location had a moderate effect is the local business owners' trust (to the) local government $($ Power $=0.355)$.

The variable that affects the variable group of age, gender, and education, and the physical structure characteristic of the business (ownership and building location) is 'the community's expectations of urban transformation strategies.' Age does not have a powerful causal effect on the physical structure characteristic of the business (ownership and building location), trust, belonging, and expectations. The literature assumes that 'the community's potential to make decisions on behalf of urban transformation strategies' will make it easier to determine the roles, institutions, and procedures that will in turn facilitate urban transformation.

In quantitative analyses, ownership, building type, and life span of business do not have a significant effect on the levels of trust, belonging, and expectations. However, education, age, gender, and place of residence have a high impact at the cognitive level of the social capital. Renters have the capacity to think on and are conscious about the future of the area.

\section{CONCLUSIONS FROM THE EMPIRICAL RESEARCH}

This study does not claim to shed new light on 'social capital.' It has only experimental value. In this research project, social capital is accepted as an important 'experiential data source' in urban studies and as a structuring tool as a 'public value' for the formation of urban policies. 
Research findings confirm that the cognitive dimension of social capital can be a tool for the development of the laws, bylaws, and organization of urban transformation. Qualitative findings show that the property condition and organizational dispersion can weaken the activity of the social capital. Quantitative findings, on the other hand, indicate that the cognitive aspect of social capital is inclined to make collective decisions. According to the results of the analyses, local business community is inclined to form the structural dimension of the social capital. The research mainly deduces that the core obstacles against the inclusion of the small enterprises in the process of urban transformation has to do with the fact that the cognitive social capital data in areas of urban transformation are not reflected in its laws, the bylaws, and initial strategies. As stated by Field [23], in the research site, the shared values of the social capital is the local conditions, and the components of these conditions have not yet been unraveled and the social capital's structural proofs have not yet formed.

According to urban transformation law, the research site is an area that is ready for transformation due to its location and spatial structure. However, according to the findings of our research, İnönü Avenue is an area that has social capital that is open to cooperation, and although it does exhibit physical and organizational weaknesses, its local business community is powerful and resilient in the face of global investments and the prospect of urban transformation. In the current situation, although there are no visible signs of effective cooperation and organization in the research site, the urban transformation law is also far removed from the expectations of the local business community. The local business community, which is ready for effective cooperation on the issues of common principles and strategies, can only overcome the obstacles through central-local partnerships and programs. In order for social capital to be able to assist in the implementation of urban transformation, its structural dimension should be brought to light. To clarify the roles, rules, and procedures for common action and cooperation, as described by Uphoff, the importance of the knowledge and values that belong to the community must be emphasized [8]. The existence of common principles and values in the research site, which have been agreed on regarding the implementation of urban transformation, can bring the structural dimension of social capital to life. In this process, the national and local governments' desire to understand and make use of social capital carries a great deal of weight. As Fukuyama [7] states, social capital can become a political instrument to the extent that it is perceived as a 'public value', and excessive intervention on the part of national governments can negatively affect social capital.

This study contributes to the experiential side of the concept of social capital, which is open to enrichment, in the form of fieldwork findings obtained by using mixed methods research in a local business community that is facing the prospect of urban transformation. In site research it was observed that mixed methods research is an important tool for gathering knowledge that is embedded in the research field. However, there are certain advantages and disadvantages to collecting data through mixed methods research [24]. The advantages and disadvantages of the mixed methods research were recorded. Particularly, embedding the qualitative analysis into the quantitative analysis through interpretation requires much attention, meticulousness, and time. It is known that using software saves time in qualitative analysis. Research team has managed to assess the analysis results without using software, but this cost a great deal of time. The fact that it takes a very long time to analyze the data is one of the disadvantages of this method. In the formation of social capital, the differentiation of the power levels of the independent variables in the qualitative analysis necessitated further quantitative analysis techniques. However, the application of mixed methods research allowed the range of data on the area to be expanded in different domains of inquiry, and the paradoxes, contradictions, and potentials of inclusivity in the process of urban transformation were discovered [25].

There is a need for a large number of studies to explain the significance of social capital in areas undergoing urban transformation. Social capital is already a very important concept used to explain 
social and cultural factors in experiential research on economic development. However, along with more research, increased number of local governments, civil society organizations, and local collectivities that will voluntarily embrace this issue is necessary for a better understanding of the importance of social capital. Improving the policies that are geared toward implementation, on the other hand, can become possible if the national and local authorities, politicians, local civil society initiatives, and opinion leaders discover the potential power of social capital in implementing urban transformation. This research can be advanced by studies that measure cognitive capital at the macro-level and by those that inquire into how it transforms into structural capital.

\section{REFERENCES}

[1] Granovetter, M., The strength of weak ties. American Journal of Sociology, 78(6), pp. 13601380, 1973. doi: http://dx.doi.org/10.1086/225469

[2] Granovetter, M., Economic action and social structure: the problem of embeddedness, American Journal of Sociology, 91(3), pp. 481-510, 1985. doi: http://dx.doi.org/10.1086/228311

[3] Castells, M., The Rise of the Network Society: The Information Age: Economy, Society, and Culture, John Wiley \& Sons, 500 pp., 2010.

[4] Bourdieu, P., The forms of capital. Handbook of Theory and Research for the Sociology of Education, ed. J.G. Richardson, Greenwood Press: New York, pp. 241-258, 1986.

[5] Coleman, J., Social capital in the creation of human capital. The American Journal of Sociology, 94, pp. 95-120, 1998. doi: http://dx.doi.org/10.1086/228943

[6] Putnam, R.D., The Prosperous Community: Social Capital and Public Life The American Prospect, Vol. 13, Routlegde: UK, pp. 35-42, 1993.

[7] Fukuyama, F., Social capital and civil society and development. Third World Quarterly, 22(1), pp. 7-20, 2001. doi: http://dx.doi.org/10.1080/713701144

[8] Uphoff, N., Understanding social capital: learning from the analysis and experience of participation. Social Capital: A Multifaceted Perspective, eds. P. Dasgupta \& I. Serageldin, The World Bank: Washington, DC, pp. 215-254, 2000.

[9] Grootaert, C. \& Bastelaer, T., Conclusion: measuring impact and drawing policy implications. The Role of Social Capital in Development: An Empirical Assessment, eds. C. Grootaert \& T. Bastelaer, Cambridge University Press, pp. 341-351, 2008. doi: http://dx.doi.org/10.1017/ cbo9780511492600.013

[10] Glaeser, E.L., Laibson, D. \& Sacerdota, B., An economic approach to social capital. The Economic Journal, 112(November), pp. 437-458, 2002. doi: http://dx.doi.org/10.1111/14680297.00078

[11] Mayer, M., The onward sweep of the social capital: understanding cities, communities and urban movements. International Journal of Urban and Regional Research, 28(1), pp. 108-130, 2003. doi: http://dx.doi.org/10.1111/1468-2427.00435

[12] Raco, M. \& Tunney, E., Visibilities and invisibilities in urban development: small business communities and the London Olympics 2012. Urban Studies, 47(10), pp. 2069-2091, 2010. doi: http://dx.doi.org/10.1177/0042098009357351

[13] Mehta, G., Redeveloping while preserving the social capital neighborhoods: the case of Dharavi, Mumbai. Made in Şişhane, ed. Aslı Kıyak İngin, Istanbul, pp. 62-77, 2011.

[14] Çekic-Inal, T. \& Okten, A.N., Re-evaluation of rural development problematic in the context of social capital. Megaron, 4(3), pp. 203-213, 2009.

[15] Altınok, E., Yasadışı Yapılaşan Alanlarda Dönüştürme Kapasitelerinin Tükenişi ve Kentsel Yoksulluk-Çeliktepe Örneği, Unpublished Master's Thesis, YTÜ, Graduate School of Natural and Applied Sciences, İstanbul, 2006. 
[16] Turkish Act 6306 on Transformation of Areas under Disaster Risk, Official Bulletin No: 28309, May 31, 2012.

[17] Hewson, C., Mixed methods. The Sage Dictionary of Social Research Methods, ed. V. Jupp, Sage Publication: London, pp. 179-180, 2006. doi: http://dx.doi.org/10.4135/9780857020116

[18] Onwuegbuzie, A. \& Leech, N.L., Linking research questions to mixed methods data analysis procedure. The Qualitative Report, 11(3), pp. 474-498, 2006.

[19] Anderson, A., Park, J. \& Jack, S., Entrepreneurial social capital: conceptualizing social capital in new high tech firms. International Small Business Review, 25(3), pp. 245-272, 2007. doi: http://dx.doi.org/10.1177/0266242607076526

[20] Driscoll, D.L., Appiah-Yeboah, A., Salib, P.J. \& Rupert, D., Merging qualitative and quantitative data in mixed research: how to and why not? Ecological and Environmental Anthropology, 3(1), pp. 19-28, 2007.

[21] Creswell, J.W., Plano Clark, V.L., Gutmann, M.L. \& Hanson, W.E., Advanced mixed methods research designs. Handbook of Mixed Methods in Social and Behavioral Research, Sage: Thousand Oaks, CA, pp. 209-240, 2003.

[22] Creswell, J., Research Design: Qualitative, Quantitative and Mixed Methods Approaches, Sage: London, p. 21, 2009.

[23] Field, J., Sosyal Sermaye (Social Capital), trans. B. Bilgen \& B. Şen, İstanbul Bilgi University Publishing: İstanbul, 2008.

[24] Johnson, B.R. \& Onwuegbuzie, A.J., Mixed methods research: a research paradigm whose time has come. Educational Researcher, 33(7), pp. 14-26, 2004. doi: http://dx.doi. org/10.3102/0013189x033007014

[25] Ozcevik, O. \& Tan, P., Do we have the right toolbox? A process of mixed-methods: a research case from an urban transformation site in İstanbul. WIT Transactions in Ecology and the Environment, 179, pp. 437-450, 2013. doi: http://dx.doi.org/10.2495/sc130371 